\title{
Synthesis of 3,4-Disubstituted 2H-Benzopyrans Through C-C Bond Formation via Electrophilic Cyclization
}

\author{
Shilpa A. Worlikar, Tanay Kesharwani, Tuanli Yao, and Richard C. Larock ${ }^{\star}$ \\ Department of Chemistry, lowa State University, Ames, lowa 50011
}

\section{Abstract}<smiles>[R]C#CCOc1ccc([R])cc1</smiles>

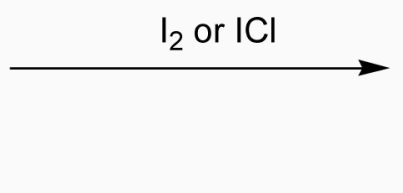<smiles>[R]C1=C(I)COc2ccc([R])cc21</smiles>

The electrophilic cyclization of substituted propargylic aryl ethers by $\mathrm{I}_{2}, \mathrm{ICl}$ and $\mathrm{PhSeBr}$ produces 3,4-disubstituted $2 \mathrm{H}$-benzopyrans in excellent yields. This methodology results in vinylic halides or selenides under mild reaction conditions, and tolerates a variety of functional groups, including methoxy, alcohol, aldehyde and nitro groups.

\section{Introduction}

$2 H$-1-Benzopyrans, commonly known as $2 H$-benzopyrans or $2 H$-chromenes, are key structural units of a variety of biologically important compounds, many of which are pharmaceutically significant. The $2 \mathrm{H}$-benzopyran Daurichromenic acid is known to exhibit anti-HIV properties, 1 while Coutareagenin possesses antidiabetic activity. ${ }^{2}$ Derivatives of 3,4-diphenylchromans are known to have estrogenic activity. ${ }^{3}$ Numerous derivatives of $2 \mathrm{H}$-benzopyrans are useful for treatment of proliferative skin disorder and microbial infections ${ }^{4}$ and show potent antifungal activity. ${ }^{5}$ Derivatives of $2 H$-benzopyrans, like 2,4 -diphenyl- $2 H$-benzopyran and 2,2,4-triphenyl- $2 H$-benzopyran, have been studied for their photochromic behavior. ${ }^{6}$ Due to their biological and pharmaceutical importance, the isolation and synthesis of $2 \mathrm{H}$-benzopyrans has received considerable attention in the literature.

Substituted $2 \mathrm{H}$-benzopyrans have been synthesized in our laboratories by the $\mathrm{Pd}(\mathrm{II})$-catalyzed cyclization of allylic aryl ethers, ${ }^{7}$ while the palladium-catalyzed cross-coupling of 4trifluoromethanesulfonyloxy- $2 \mathrm{H}$-benzopyrans with arylboronic acids has also been reported in the literature. ${ }^{8}$ Syntheses of $2 \mathrm{H}$-benzopyrans are also known using platinum and gold catalysis, ${ }^{9} \mathrm{Hg}(\mathrm{II})$-mediated cyclizations, ${ }^{10}$ Grignard reagents, ${ }^{11}$ and microwave irradiation. 12

A wide range of carbocycles and heterocycles have been constructed using the electrophilic cyclization of disubstituted alkynes ${ }^{13}$ and transition metal-catalyzed cyclizations. ${ }^{14,15}$ Many researchers, including those from our group, have utilized these cyclizations for the synthesis of benzofurans, ${ }^{16}$ furans, ${ }^{17}$ benzo[b]thiophenes, ${ }^{18}$ thiophenes, ${ }^{19}$ naphthols, ${ }^{20}$ indoles, ${ }^{21}$

larock@iastate.edu.

Supporting Information Available: General experimental procedures and spectral data for all previously unreported starting materials and products. This material is available free of charge via the Internet at http://pubs.acs.org. 
quinolines, ${ }^{22}$ isoquinolines, ${ }^{23}$ isocoumarins, ${ }^{24}$ isochromenes ${ }^{25}$ and polycyclic aromatics.

26 Some methods are not compatible with functionality, while some require the use of costly metals as catalysts. Recently Barluenga and co-workers reported the synthesis of $2 \mathrm{H}$ -

benzopyrans by the cyclization of aryl propargylic ethers using costly $\mathrm{IPy}_{2} \mathrm{BF}_{4}$ and $\mathrm{HBF}_{4} \cdot{ }^{27}$ They also reported two examples of the iodocyclization of propargylic ethers using $\mathrm{I}_{2}$ in water. We report herein many examples and a general synthesis of $2 \mathrm{H}$-benzopyrans in good yields via electrophilic cyclization using the simple, inexpensive electrophiles $\mathrm{I}_{2}, \mathrm{ICl}$, and $\mathrm{PhSeBr}$ in nitromethane.

\section{Results and Discussion}

Our early studies mainly focused on the iodocyclization of substituted propargylic aryl ethers to give 3,4-disubstituted $2 \mathrm{H}$-benzopyrans in excellent yields. Phenyl 3-phenyl-2-propynyl ether (1) was used as a model system for optimization of the reaction conditions using $I_{2}$ or $\mathrm{ICl}($ eq 1$)$.

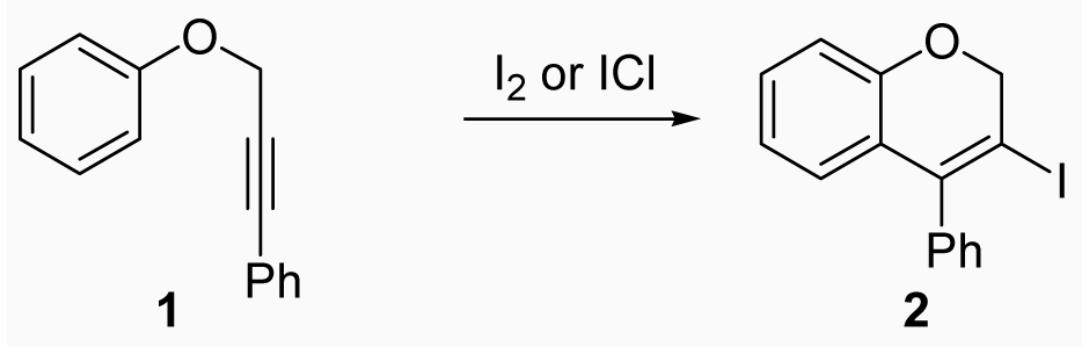

Early in this work, conditions similar to our previous iodocyclization reactions were used. For instance, the reaction was run with $0.25 \mathrm{mmol}$ of $\mathbf{1}, 2$ equiv of $\mathrm{NaHCO}_{3}$ as the base, and 3 equiv of $\mathrm{I}_{2}$ in $5 \mathrm{ml}$ of $\mathrm{CH}_{3} \mathrm{CN}$ at $25^{\circ} \mathrm{C}$ to obtain a $61 \%$ isolated yield of the desired 3-iodo-4phenyl-2H-benzopyran (2)27 (Table 1, entry 1). Solvents, like $\mathrm{CH}_{2} \mathrm{Cl}_{2}, \mathrm{CH}_{3} \mathrm{OH}$ and DMF, resulted in lower yields (entries 2-4), but $\mathrm{CH}_{3} \mathrm{NO}_{2}$ gave a yield of $77 \%$ (entry 5). No reaction was observed at $0{ }^{\circ} \mathrm{C}$ after $4 \mathrm{~h}$ (entry 6 ), while the reaction was messy and produced only a $42 \%$ yield at $40{ }^{\circ} \mathrm{C}$ (entry 7 ). Reducing the amount of $\mathrm{I}_{2}$ to 2 equiv decreased the yield significantly to $53 \%$ (entry 8), while an increase in the number of equivalents of $\mathrm{I}_{2}$ caused a slight decrease in the yield to $69 \%$ (entry 9). Reducing the reaction time to $12 \mathrm{~h}$ lowered the yield to $62 \%$ (entry 10), while there was no increase in yield when the reaction time was doubled to $48 \mathrm{~h}$ (entry 11). The presence of the base proved to be important for the reaction as the yield was reduced to $58 \%$ without the base and only $70 \%$ with one equiv of the base (entries 12 and 13). Several additional bases were examined in this reaction, but $\mathrm{NaHCO}_{3}$ was found to give the best yield (entries 14-16).

In our previous cyclizations, $\mathrm{ICl}$ has proven to be a better electrophile for some substrates. Therefore, with a view to obtaining better yields, the cyclization of phenyl 3-phenyl-2-propynyl ether (1) was optimized using $\mathrm{ICl}$ as the electrophile, starting with our previously developed conditions. Because of the importance of the solvent in such reactions, the reaction was carried out using $\mathrm{CH}_{2} \mathrm{Cl}_{2}$, diethyl ether, THF, hexane, $\mathrm{CH}_{3} \mathrm{OH}$ and $\mathrm{CH}_{3} \mathrm{NO}_{2}$ at low temperatures (Table 2, entries 1-6). The solvent $\mathrm{CH}_{3} \mathrm{NO}_{2}$ gave the best yield of $69 \%$, but the temperature had to be raised to $-25{ }^{\circ} \mathrm{C}$. The reaction was run at $-25^{\circ} \mathrm{C}$ with the second best solvent for the reaction, namely $\mathrm{CH}_{2} \mathrm{Cl}_{2}$, to get a slightly lower yield of $65 \%$ (entry 7). In all of these reactions, $\mathrm{NaHCO}_{3}$ was used as a base. The yield increased to $96 \%$ when the reaction was carried out without $\mathrm{NaHCO}_{3}$ (entry 8). Increasing the temperature to $0{ }^{\circ} \mathrm{C}$ gave undetermined side products with the desired compound being formed in less than a 5\% yield (entry 9). Decreasing or 
increasing the amount of ICl gave slightly lower yields (entries 10 and 11). Thus, our optimized conditions using $\mathrm{ICl}$ are $0.25 \mathrm{mmol}$ of $\mathbf{1}, 1.5$ equiv of $\mathrm{ICl}$ and $5 \mathrm{ml}$ of $\mathrm{CH}_{3} \mathrm{NO}_{2}$ at $-25{ }^{\circ} \mathrm{C}$.

After obtaining our best conditions using either $\mathrm{I}_{2}$ or $\mathrm{ICl}$, we decided to study the scope of this reaction on various substrates. Ethers 1, 4, 5 and $\mathbf{6}$ were obtained by standard Sonogashira chemistry 28 using commercially available starting materials (Scheme 1). Ethers $\mathbf{9}$ and $\mathbf{1 0}$ were obtained by a two step approach, the first step being the synthesis of the substituted aryl

propargylic ethers $\mathbf{7}$ and $\mathbf{8}$, followed by Sonogashira chemistry (Scheme 2). Ethers 11, 12 and 13 were synthesized by a Mitsunobu reaction (Scheme 3), while ethers 14,29 15,30 16,30 17, $27 \mathbf{1 8}^{, 31} \mathbf{1 9}^{, 31} \mathbf{2 0}, 31 \mathbf{2 1}^{32}$ and $\mathbf{2 2}^{33}$ (refer to Table 3 ) were previously reported in the literature.

Cyclizations were then carried out using our optimized conditions for $\mathrm{I}_{2}$ (conditions A) or ICl (conditions B). 3,4-Disubstituted $2 \mathrm{H}$-benzopyrans were obtained in good yields using $\mathrm{I}_{2}$ or ICl when the substituent on the propargylic alkyne was either a simple phenyl or an alkenyl group (Table 3, entries 1, 2, 32 and 33). An alkyl substituent on the alkyne terminus did not give the desired product with $\mathrm{I}_{2}$ or $\mathrm{ICl}$ as the electrophile, but worked with $\mathrm{PhSeBr}$ (entries 34-36).

However, an hydroxymethyl-substituted alkyne gave good yields with $\mathrm{I}_{2}$, as well as ICl (entries 37 and 38). Simple phenyl propargyl ether (3) failed to give any of the desired product with $\mathrm{I}_{2}$ or $\mathrm{ICl}$ (entries 30 and 31 ).

The introduction of substituents on the aryl groups has a considerable effect on the yield of the reaction. Substituents were first introduced onto the aromatic ring attached to the alkyne. Electron-donating groups, like $\mathrm{Me}$ and $\mathrm{MeO}$ in the para or ortho positions, gave good yields (entries 4-7, 10 and 11), while an electron-withdrawing group, like $\mathrm{a} \mathrm{NO}_{2}$ group, gave relatively poor yields of 59\% with $\mathrm{I}_{2}$ and 53\% with $\mathrm{ICl}$ (entries 8 and 9). Introducing substituents onto the aromatic ring attached to the oxygen moiety also has a pronounced effect. Electron-donating groups, like $\mathrm{Me}, t$ - $\mathrm{Bu}$ and $\mathrm{MeO}$, on the phenyl ring para to the oxygen gave better yields with $\mathrm{I}_{2}$ as the electrophile (entries 12,14 and 16) than those obtained using $\mathrm{ICl}$ (entries 13,15 and 17). Compound $\mathbf{3 0}$ was thus obtained in improved yields without the use of ion exchange resins as additives, as was reported by Barluenga. ${ }^{27}$ The sterically-hindered ether $\mathbf{1 0}$ also gave good results (entries 23 and 24).

Placing an electron-withdrawing chlorine in the position para to the oxygen gave somewhat lower yields (entries 18 and 19) of the desired isomer. An aldehyde group in the position para to the oxygen gave a mixture of two inseparable regioisomers, the ratio of which depended on the electrophile used and the reaction temperature (entries 20 and 21). The benzopyran isomer was favored when the reaction was carried out at $-78{ }^{\circ} \mathrm{C}$ with $\mathrm{CH}_{2} \mathrm{Cl}_{2}$ as the solvent and $\mathrm{ICl}$ as the electrophile (entry 22).

In order to study the regiochemistry of cyclization, the reaction was carried out with substituents meta to the oxygen moiety. A sterically bulky $t$-Bu group in the meta position gave selectively one product 35 (entries 25 and 26). A less bulky $\mathrm{Cl}$ in the meta position gave two regioisomers $\mathbf{3 6}$ and $\mathbf{3 7}$ (entries 27 and 28), while a $\mathrm{MeO}$ group gave a similar mixture of two inseparable regioisomers $\mathbf{3 8}$ and $\mathbf{3 9}$ (entry 29). $\alpha$-Naphthyl propargylic ether $\mathbf{1 3}$ also gave the desired compound $\mathbf{4 3}$ in modest yields (entries 39 and 40).

Phenyl 3-phenyl-2-propynyl ether (3) gave a 95\% yield of the cyclized product $\mathbf{2 3}$ when $\mathrm{PhSeBr}$ was used as the electrophile (entry 3). Surprisingly, ether 21, which failed to give the desired product with $\mathrm{I}_{2}$ or ICl, gave a $79 \%$ yield of compound $\mathbf{4 1}$ with $\mathrm{PhSeBr}$ as the electrophile (entry 36).

We believe that the mechanism of these cyclizations involves initial formation of an iodonium or selenonium intermediate by attack of the electrophile on the triple bond, followed by 
electrophilic attack on the electron cloud of the aromatic ring. Loss of a proton gives the $2 \mathrm{H}$ benzopyran (Scheme 4).

During our cyclization studies, ether 9 gave a mixture of two isomers, one being the expected benzopyran product and the other a possible five-membered ring dihydrofuran product. This encouraged us to confirm the structure of our cyclized product $\mathbf{2}$ using X-ray crystallography (see the Supporting Information), which indeed proved to be a $2 \mathrm{H}$-benzopyran.

The iodo- $(2 H)$-benzopyrans obtained by iodocyclization appear highly promising as intermediates for the preparation of more highly substituted benzopyrans. Indeed 3iodobenzopyrans, like the ones prepared here, have recently been further elaborated by palladium-catalysed cross-coupling reactions. ${ }^{27}$ To further prove the utility of our methodology, we have carried out the palladium/copper-catalyzed reaction of our product 2 with 5-ethynyl-2-fluorotoluene to obtain $\mathbf{4 4}$ in an $87 \%$ yield. Palladium catalysed CO insertion in our product $\mathbf{4 2}$ gave compound $\mathbf{4 5}$ in an overall $\mathbf{7 2} \%$ yield (Scheme 5).

\section{Conclusions}

3,4-Disubstituted $2 \mathrm{H}$-benzopyrans have been obtained from starting materials that are easy to synthesize. The reaction conditions are mild and the products are easy to isolate in good yields. The iodine moiety in the products provides a useful handle for further functionalization of the resulting heterocycles. A polycyclic Sonogashira product $\mathbf{4 4}$ has been obtained in a good yield. Our methodology tolerates functional groups, including alcohol, aldehyde, methoxy and nitro groups. In addition to $\mathrm{I}_{2}$ and $\mathrm{ICl}, \mathrm{PhSeBr}$ has also been used as the electrophile. The structure of 3-iodo-4-phenyl-2H-benzopyran (2) has been confirmed by X-ray crystallography.

\section{Experimental Section}

\section{General procedure for the palladium/copper-catalyzed reaction of phenyl} propargyl ether with aryl halides-To a solution of $2.5 \mathrm{mmol}$ of the aryl halide in $\mathrm{Et}_{3} \mathrm{~N}$ $(15 \mathrm{ml})$ was added $\mathrm{PdCl}_{2}\left(\mathrm{PPh}_{3}\right)_{2}(2 \mathrm{~mol} \%)$, which was then stirred for $5 \mathrm{~min}$. $\mathrm{CuI}(1.5 \mathrm{~mol}$ $\%$ ) was then added and the flask was sealed and flushed with Ar. The reaction was stirred for $20 \mathrm{~min}$. A solution of $3.0 \mathrm{mmol}$ of phenyl propargyl ether in $2 \mathrm{~mL}$ of $\mathrm{Et}_{3} \mathrm{~N}$ was then added dropwise and the reaction mixture was allowed to stir at room temperature for the desired time. After the reaction was over, the resulting solution was diluted with $\mathrm{H}_{2} \mathrm{O}(10 \mathrm{ml})$ and extracted with diethyl ether $(3 \times 15 \mathrm{~mL})$. The combined ether fractions were dried over anhydrous $\mathrm{Na}_{2} \mathrm{SO}_{4}$ and concentrated under vacuum to yield the crude product. The crude product was purified by flash chromatography on silica gel using ethyl acetate/hexanes as the eluent.

Phenyl 3-p-tolylprop-2-yn-1-yl ether (4)-This compound was obtained as a white solid: mp 71-72 ${ }^{\circ} \mathrm{C} ;{ }^{1} \mathrm{H}$ NMR $\left(300 \mathrm{MHz}, \mathrm{CDCl}_{3}\right) \delta 2.30(\mathrm{~s}, 3 \mathrm{H}), 4.86(\mathrm{~s}, 2 \mathrm{H}), 6.94-7.08(\mathrm{~m}, 5 \mathrm{H})$, 7.18-7.33 (m, 4H); ${ }^{13} \mathrm{C}$ NMR (75 MHz, $\left.\mathrm{CDCl}_{3}\right) \delta 21.7,56.9,83.5,87.5,115.2,119.5,121.6$, 129.3, 129.7, 132.0, 139.0, 158.1; IR (neat, $\mathrm{cm}^{-1}$ ) 3032, 2914, 1598, 1490, 1214, 1029; HRMS $\mathrm{m} / \mathrm{z} 222.10477$ (calcd $\mathrm{C}_{16} \mathrm{H}_{14} \mathrm{O}, 222.10447$ ).

\section{General procedure for the palladium/copper-catalyzed reaction of terminal} alkynes with iodobenzene-To a solution of $4.5 \mathrm{mmol}$ of iodobenzene in $\mathrm{Et}_{3} \mathrm{~N}(15 \mathrm{ml})$, was added $\mathrm{PdCl}_{2}\left(\mathrm{PPh}_{3}\right)_{2}(2 \mathrm{~mol} \%)$, and $\mathrm{CuI}(1.5 \mathrm{~mol} \%)$, and the mixture was stirred for 30 min under Ar. A solution of $3.0 \mathrm{mmol}$ of the terminal alkyne in $2 \mathrm{~mL}$ of $\mathrm{Et}_{3} \mathrm{~N}$ was then added dropwise and the reaction mixture was allowed to stir at room temperature for the desired time. After the reaction was over, the resulting solution was diluted with $\mathrm{H}_{2} \mathrm{O}(10 \mathrm{ml})$ and extracted with diethyl ether $(3 \times 15 \mathrm{~mL})$. The combined ether fractions were dried over anhydrous $\mathrm{Na}_{2} \mathrm{SO}_{4}$ and concentrated under vacuum to yield the crude product. The crude product was purified by flash chromatography on silica gel using ethyl acetate/hexanes as the eluent. 
4-(3-Phenylprop-2-yn-1-yloxy)benzaldehyde (9)-This compound was obtained as a brown solid: $\mathrm{mp} 86-87^{\circ} \mathrm{C} ;{ }^{1} \mathrm{H}$ NMR $\left(300 \mathrm{MHz}, \mathrm{CDCl}_{3}\right) \delta 5.00(\mathrm{~s}, 2 \mathrm{H}), 7.14(\mathrm{~d}, J=8.8 \mathrm{~Hz}$, $2 \mathrm{H}), 7.25-7.32(\mathrm{~m}, 3 \mathrm{H}), 7.41-7.44(\mathrm{~m}, 2 \mathrm{H}), 7.87(\mathrm{~d}, J=8.8 \mathrm{~Hz}, 2 \mathrm{H}), 9.90(\mathrm{~s}, 1 \mathrm{H}) ;{ }^{13} \mathrm{C} \mathrm{NMR}$ $\left(75 \mathrm{MHz}, \mathrm{CDCl}_{3}\right) \delta 57.0,82.9,88.1,115.4,122.0,128.5,129.1,130.6,132.0,132.1,162.8$, 191.0; IR (neat, $\mathrm{cm}^{-1}$ ) 3078, 2827, 1690, 1598, 1250, 1009; HRMS m/z 236.08409 (calcd $\mathrm{C}_{16} \mathrm{H}_{12} \mathrm{O}_{2}$, 236.08373).

\section{General procedure for the triphenylphosphine/diethyl azodicarboxylate- promoted formation of the substituted phenyl propargylic ethers-To a solution of $1.31 \mathrm{~g}$ of $\mathrm{PPh}_{3}(5.0 \mathrm{mmol})$ in dry benzene $(15 \mathrm{ml})$ was added the substituted propargylic alcohol $(5.0 \mathrm{mmol})$ and the substituted phenol $(5.0 \mathrm{mmol})$ under an inert atmosphere with stirring. Diethyl azodicarboxylate $(0.87 \mathrm{~g}, 5.0 \mathrm{mmol})$ was then added slowly and the reaction mixture was stirred at r.t. for 18 to $36 \mathrm{~h}$. After the reaction was complete, the solvent was evaporated under reduced pressure and the crude product was purified by flash chromatography on silica gel using hexanes/ethyl acetate as the eluent.}

3-tert-Butylphenyl 3-phenylprop-2-yn-1-y1 ether (11)-This compound was obtained as a yellow oil: ${ }^{1} \mathrm{H}$ NMR $\left(300 \mathrm{MHz}, \mathrm{CDCl}_{3}\right) \delta 1.30(\mathrm{~s}, 9 \mathrm{H}), 4.86(\mathrm{~s}, 2 \mathrm{H}), 6.83(\mathrm{dd}, J=8.0,2.3$ $\mathrm{Hz}, 1 \mathrm{H}), 6.96-7.02(\mathrm{~m}, 1 \mathrm{H}), 7.08(\mathrm{t}, J=1.9 \mathrm{~Hz}, 1 \mathrm{H}), 7.19-7.25(\mathrm{~m}, 4 \mathrm{H}), 7.39-7.42(\mathrm{~m}$, $2 \mathrm{H}) ;{ }^{13} \mathrm{C}$ NMR $\left(75 \mathrm{MHz}, \mathrm{CDCl}_{3}\right) \delta 31.4,34.8,56.6,84.3,87.2,111.2,113.1,118.6,122.4$, 128.4, 128.7, 129.1, 131.9, 153.0, 157.7; IR (neat, $\mathrm{cm}^{-1}$ ) 3067, 2955, 2868, 1588, 1485, 1270, 1029; HRMS m/z 264.15187 (calcd $\mathrm{C}_{19} \mathrm{H}_{20} \mathrm{O}, 264.15142$ ).

General procedure for iodocyclization-To a solution of $0.25 \mathrm{mmol}$ of the ether and 3 $\mathrm{mL}$ of $\mathrm{CH}_{3} \mathrm{NO}_{2}, 2.0$ equiv of $\mathrm{NaHCO}_{3}$ and 3.0 equiv of $\mathrm{I}_{2}$ dissolved in $2 \mathrm{~mL}$ of $\mathrm{CH}_{3} \mathrm{NO}_{2}$ was added gradually. The reaction mixture was allowed to stir at room temperature for the desired time. Alternatively, to a solution of $0.25 \mathrm{mmol}$ of the ether and $3 \mathrm{~mL}$ of $\mathrm{CH}_{3} \mathrm{NO}_{2}$ at -25 to $-30{ }^{\circ} \mathrm{C}, 1.5$ equiv of $\mathrm{ICl}$ dissolved in $2 \mathrm{~mL}$ of $\mathrm{CH}_{3} \mathrm{NO}_{2}$ was added gradually. The reaction mixture was allowed to stir at -25 to $-30{ }^{\circ} \mathrm{C}$ for the desired time. The excess $\mathrm{I}_{2}$ or $\mathrm{ICl}$ was removed by washing with satd aq $\mathrm{Na}_{2} \mathrm{~S}_{2} \mathrm{O}_{3}$. The mixture was then extracted by diethyl ether $(3 \times 10 \mathrm{~mL})$. The combined ether layers were dried over anhydrous $\mathrm{Na}_{2} \mathrm{SO}_{4}$ and concentrated under vacuum to yield the crude product, which was purified by flash chromatography on silica gel using hexanes/ethyl acetate as the eluent.

3-Iodo-4-phenyl-2 $\mathbf{H}$-benzopyran (2)-This compound was obtained as a pale yellow solid: mp 99-100 ${ }^{\circ} \mathrm{C} ;{ }^{1} \mathrm{H}$ NMR $\left(300 \mathrm{MHz}, \mathrm{CDCl}_{3}\right) \delta 5.06(\mathrm{~s}, 2 \mathrm{H}), 6.61(\mathrm{dd}, J=7.7,1.6 \mathrm{~Hz}$, $1 \mathrm{H}), 6.76(\mathrm{dt}, J=7.7,1.1 \mathrm{~Hz}, 1 \mathrm{H}), 6.85(\mathrm{dd}, J=8.0,1.0 \mathrm{~Hz}, 1 \mathrm{H}), 7.14(\mathrm{dd}, J=7.9,1.6 \mathrm{~Hz}$, $1 \mathrm{H}), 7.18-7.22(\mathrm{~m}, 2 \mathrm{H}), 7.39-7.46(\mathrm{~m}, 3 \mathrm{H}) ;{ }^{13} \mathrm{C} \mathrm{NMR}\left(75 \mathrm{MHz}, \mathrm{CDCl}_{3}\right) \delta 75.1,91.2,116.1$, 121.7, 124.2, 126.5, 128.3, 128.7, 129.5, 129.7, 140.0, 142.0, 153.3; IR (neat, $\mathrm{cm}^{-1}$ ) 3062, 2904, 1475, 1219, 1029, 994; HRMS m/z 333.98600 (calcd $\mathrm{C}_{15} \mathrm{H}_{11} \mathrm{IO}, 333.98547$ ).

General procedure for the $\mathrm{PhSeBr}$ cyclizations-To a solution of $0.25 \mathrm{mmol}$ of the substituted phenyl propargylic ether and $\mathrm{CH}_{2} \mathrm{Cl}_{2}(3 \mathrm{~mL}), 0.375 \mathrm{mmol}$ of $\mathrm{PhSeBr}$ dissolved in $2 \mathrm{~mL}$ of $\mathrm{CH}_{2} \mathrm{Cl}_{2}$ was added dropwise. The mixture was allowed to stir at room temperature for the desired time. The reaction mixture was washed with $20 \mathrm{~mL}$ of water and extracted with diethyl ether $(3 \times 10 \mathrm{~mL})$. The combined ether layers were dried over anhydrous $\mathrm{Na}_{2} \mathrm{SO}_{4}$ and concentrated under vacuum to yield the crude product, which was further purified by flash chromatography on silica gel using hexanes/ethyl acetate as the eluent.

4-Phenyl-3-phenylselenyl-2 $\mathbf{H}$-benzopyran (23)-This compound was obtained as a brown oil: ${ }^{1} \mathrm{H}$ NMR $\left(300 \mathrm{MHz}, \mathrm{CDCl}_{3}\right) \delta 4.84(\mathrm{~s}, 2 \mathrm{H}), 6.84-6.87(\mathrm{~m}, 2 \mathrm{H}), 6.94(\mathrm{t}, J=7.4 \mathrm{~Hz}$, 1H), 7.12-7.25 (m, 5H), 7.27-7.34 (m, 4H), 7.40-7.44 (m, 2H); ${ }^{13} \mathrm{C} \mathrm{NMR} \mathrm{(75} \mathrm{MHz,} \mathrm{CDCl}_{3}$ ) 
$\delta 29.9,71.1,115.3,121.4,124.0,128.2,128.4,128.8,129.1,129.2,129.2,129.3,129.6,134.6$, 141.0, 158.4; IR (neat, $\mathrm{cm}^{-1}$ ) 3052, 2919, 1582, 1480, 1224, 1024; HRMS m/z 364.03707 (calcd $\mathrm{C}_{21} \mathrm{H}_{16} \mathrm{OSe}, 364.03664$ ).

3-(4-Fluoro-3-methylphenylethynyl)-4-phenyl-2 $\mathrm{H}$-benzopyran (44)-This compound was prepared by the following procedure. To a solution of $0.17 \mathrm{~g}$ of 3-iodo-4phenyl-2H-benzopyran (2) $(0.5 \mathrm{mmol})$ in $\mathrm{Et}_{3} \mathrm{~N}(5 \mathrm{ml})$, was added $\mathrm{PdCl}_{2}\left(\mathrm{PPh}_{3}\right)_{2}(2 \mathrm{~mol} \%)$ and $\mathrm{CuI}(1.5 \mathrm{~mol} \%)$, and the mixture was stirred for $30 \mathrm{~min}$ under Ar. 0.6 Mmol of 5-ethynyl-2fluorotoluene dissolved in $1 \mathrm{~mL}$ of $\mathrm{Et}_{3} \mathrm{~N}$ was then added dropwise and the reaction mixture was allowed to stir at room temperature for $24 \mathrm{~h}$. The reaction was monitored by TLC and an additional $0.4 \mathrm{mmol}$ of the 5-ethynyl-2-fluorotoluene dissolved in $1 \mathrm{~mL}$ of $\mathrm{Et}_{3} \mathrm{~N}$ was added slowly under an inert atmosphere and the reaction mixture was further allowed to stir at room temperature for another $24 \mathrm{~h}$. After the reaction was over, the resulting solution was diluted with $\mathrm{H}_{2} \mathrm{O}(5 \mathrm{ml})$ and extracted with diethyl ether $(3 \times 10 \mathrm{~mL})$. The combined ether fractions were dried over anhydrous $\mathrm{Na}_{2} \mathrm{SO}_{4}$ and concentrated under vacuum to yield the crude product, which was purified by flash chromatography on silica gel using hexanes/ethyl acetate as the eluent to obtain the desired compound $\mathbf{4 4}$ in an $87 \%$ yield as a pale yellow solid: $\mathrm{mp} 79-80^{\circ}$ $\mathrm{C} ;{ }^{1} \mathrm{H}$ NMR $\left(300 \mathrm{MHz}, \mathrm{CDCl}_{3}\right) \delta 2.18(\mathrm{~d}, J=1.6 \mathrm{~Hz}, 3 \mathrm{H}), 4.88(\mathrm{~s}, 2 \mathrm{H}), 6.81-6.93(\mathrm{~m}, 4 \mathrm{H})$, 6.97-7.05 (m, 2H), 7.10-7.21 (m, 1H), 7.39-7.45 (m, 5H); ${ }^{13} \mathrm{C} \mathrm{NMR}\left(100 \mathrm{MHz}, \mathrm{CDCl}_{3}\right) \delta 14.6$ $(\mathrm{d}, J=3.4 \mathrm{~Hz}), 68.0,86.7(\mathrm{~d}, J=1.9 \mathrm{~Hz}), 95.1(\mathrm{~d}, J=0.8 \mathrm{~Hz}), 112.4,115.3(\mathrm{~d}, J=9.4 \mathrm{~Hz})$, $116.4,118.9(\mathrm{~d}, J=3.8 \mathrm{~Hz}), 121.8,124.3,125.3(\mathrm{~d}, J=18.2 \mathrm{~Hz}), 126.8,128.2(\mathrm{~d}, J=10.2$ $\mathrm{Hz}), 129.8,130.2,130.8(\mathrm{~d}, J=8.4 \mathrm{~Hz}), 134.7(\mathrm{~d}, J=5.7 \mathrm{~Hz}), 136.6,140.8,154.6,160.1$, 162.6; IR (neat, $\mathrm{cm}^{-1}$ ) 3047, 2919, 2192, 1480, 1224, 1106; HRMS m/z 340.12694 (calcd $\left.\mathrm{C}_{24} \mathrm{H}_{17} \mathrm{FO}, 340.12634\right)$.

1,4-Dihydro-2,5-dioxacyclopenta[a]naphthalen-3-one (45)-This compound was prepared by the following procedure. To a solution of $0.14 \mathrm{~g}$ of 4-hydroxymethyl-3-iodo- $2 \mathrm{H}$ benzopyran (42) $(0.5 \mathrm{mmol})$ in DMF (5 ml) was added $\mathrm{PdCl}_{2}\left(\mathrm{PPh}_{3}\right)_{2}(5 \mathrm{~mol} \%)$ and $\mathrm{K}_{2} \mathrm{CO}_{3}$ (2 equiv), and the mixture was stirred for $6 \mathrm{~h}$ under an atmosphere of $\mathrm{CO}$ at $60^{\circ} \mathrm{C}$. The reaction was monitored by TLC and, after completion of the reaction, the resulting solution was cooled to room temperature, diluted with ether $(15 \mathrm{ml})$, and washed with brine $(15 \mathrm{ml})$. The aqueous layer was extracted with diethyl ether $(3 \times 15 \mathrm{~mL})$. The combined ether fractions were dried over anhydrous $\mathrm{Na}_{2} \mathrm{SO}_{4}$ and concentrated under vacuum to yield the crude product, which was purified by flash chromatography on silica gel using hexanes/ethyl acetate as the eluent to obtain the desired compound $\mathbf{4 5}$ in an $72 \%$ yield as a brown solid: mp 151-152 ${ }^{\circ} \mathrm{C} ;{ }^{1} \mathrm{H}$ NMR $\left(400 \mathrm{MHz}, \mathrm{CDCl}_{3}\right)$ 5.13-5.15 (m, 4H), 6.92-6.99 (m, 2H), 7.07 (dd, J = 7.5, $\left.1.5 \mathrm{~Hz}, 1 \mathrm{H}\right), 7.34$ $(\mathrm{dt}, J=8.2,0.8 \mathrm{~Hz}, 1 \mathrm{H}) ;{ }^{13} \mathrm{C} \mathrm{NMR}\left(100 \mathrm{MHz}, \mathrm{CDCl}_{3}\right) \delta 63.3,68.8,116.4,117.2,118.3,122.0$, 124.2, 133.8, 154.1, 154.8, 170.7; IR (neat, $\mathrm{cm}^{-1}$ ) 2361, 1744, 1666, 1449, 1336, 1181, 1052; HRMS m/z 188.04776 (calcd $\mathrm{C}_{11} \mathrm{H}_{8} \mathrm{O}_{3}, 188.04743$ ).

\section{Supplementary Material}

Refer to Web version on PubMed Central for supplementary material.

\section{Acknowledgements}

We thank the National Institute of General Medical Sciences (GM070620) and the National Institutes of Health Kansas University Chemical Methodologies and Library Development Center of Excellence (P50 GM069663) for support of this research, Johnson Matthey, Inc., and Kawaken Fine Chemicals Co., Ltd., for donations of palladium catalysts and Dr. Arkady Ellern and the Molecular Structure Laboratory of Iowa State University for the single crystal X-ray results. 


\section{References}

1. (a) Zhendong J, Ying K. PCT Int. Appl 2004;25 (b) Iwata N, Wang N, Yao X, Kitanaka S. J. Nat. Prod 2004;67:1106. [PubMed: 15270561] (c) Hu H, Harrison TJ, Wilson PD. J. Org. Chem 2004;69:3782. [PubMed: 15153009]

2. Korec R, Sensch KH, Zoukas T. Arzneim. Forsch 2000;50:122. [PubMed: 10719614]

3. (a) Carney RWJ, Bencze WL, Wojtkunski J, Renzi AA, Dorfman L, De Stevens G. J. Med. Chem 1966;9:516. [PubMed: 5968016] (b) Gauthier S, Caron B, Cloutier J, Dory YL, Favre A, Larouche D, Mailhot J, Ouellet C, Schwerdtfeger A, Leblanc G, Martel C, Simard J, Merand Y, Belanger A, Labrie C, Labrie F. J. Med. Chem 1967;40:2117. [PubMed: 9216828]

4. Bonadies F, Di Fabio R, Bonini C. J. Org. Chem 1984;49:1647.

5. Morandim AA, Bergamo DCB, Kato MJ, Cavalheiro AJ, Bolzani VS, Furlan M. Phytochem. Anal 2005;16:282. [PubMed: 16042156]

6. (a) Martins CI, Coelho PJ, Carvalho LM, Oliveira-Campos AMF, Samat A, Guglielmetti R. Helv. Chim. Acta 2003;86:570. (b) Kodama Y, Nakabayashi T, Segawa K, Hattori E, Sakuragi M, Nishi N, Sakuragi H. J. Phys. Chem. A 2000;104:11478. (c) Padwa A, Andrew A, Lee GA, Owens W. J. Org. Chem 1975;40:1142.

7. Larock RC, Wei L, Hightower TR. Synlett 1998:522.

8. Eguchi T, Hoshino Y, Ayame A. Bull. Chem. Soc. Jpn 2002;75:581.

9. (a) Pastine SJ, Youn SW, Sames D. Tetrahedron 2003;59:8859. (b) Nevado C, Echavarren AM. Chem. Eur. J 2005;11:3155.

10. Balasubramanian T, Balasubramanian KK. Tetrahedron Lett 1991;32:6641.

11. Kirkiacharian BS, Danan A, Koutsourakis PG. Synthesis 1991;10:879.

12. Dintzner MR, Lyons TW, Akroush MH, Wucka P, Rzepka AT. Synlett 2005:1046.

13. (a) Knight DW, Redfern AL, Gilmore J. J. Chem. Soc., Perkin Trans. 1 2002:622. (b) Bellina F, Biagetti M, Carpita A, Rossi R. Tetrahedron Lett 2001;42:2859. (c) Bellina F, Biagetti M, Carpita A, Rossi R. Tetrahedron 2001;57:2857. (d) Djuardi E, McNelis E. Tetrahedron Lett 1999;40:7193. (e) Marshall JA, Yanik MM. J. Org. Chem 1999;64:3798. (f) Knight DW, Redfern AL, Gilmore. J. Chem. Commun 1998:2207. (g) Redfern AL, Gilmore J. Synlett 1998:731. (h) Ren XF, Konaklieva MI, Shi H, Dicy H, Lim DV, Gonzales J, Turos E. J. Org. Chem 1998;63:8898. (i) Bew SP, Knight DW. Chem. Commun 1996:1007. (j) El-Taeb GMM, Evans AB, Jones S, Knight DW. Tetrahedron Lett 2001;42:5945.

14. For a review, see: Larock RC. Top. Organomet. Chem 2005;14:147.

15. (a) Roesch KR, Larock RC. Org. Lett 1999;4:553. (b) Nan Y, Miao H, Yang Z. Org. Lett 2000;2:297. [PubMed: 10814306] (c) Nevado C, Echavarren AM. Synthesis 2005:167. (d) Larock RC, Yum EK. J. Am. Chem. Soc 1991;113:6689. (e) Larock RC, Yum EK, Refvik MD. J. Org. Chem 1998;63:7652. (f) Roesch KR, Larock RC. J. Org. Chem 1998;63:5306. (g) Cacchi S, Fabrizi G, Moro L. Tetrahedron Lett 1998;39:5101. (h) Cacchi S, Fabrizi G, Moro L. Synlett 1998:741. (i) Arcadi A, Cacchi S, Rosario MD, Fabrizi G, Marinelli F. J. Org. Chem 1996;61:9280. (j) Cacchi S, Carnicelli V, Marinelli F. J. Organomet. Chem 1994;475:289. (k) Arcadi A, Cacchi S, Marinelli F. Tetrahedron Lett 1992;33:3915. (1) Cacchi S. J. Organomet. Chem 1999;576:42.

16. (a) Arcadi A, Cacchi S, Fabrizi G, Marinelli F, Moro L. Synlett 1999:1432. (b) Yue D, Yao T, Larock RC. J. Org. Chem 2005;70:10292. [PubMed: 16323837] (c) Larock RC, Stinn DE. Tetrahedron Lett 1988;29:4687.

17. (a) Sniady A, Wheeler KA, Dembinski R. Org. Lett 2005;7:1769. [PubMed: 15844902] (b) Yao T, Zhang X, Larock RC. J. Am. Chem. Soc 2004;126:11164. [PubMed: 15355093] (c) Larock RC, Liu CL. J. Org. Chem 1983;48:2151.

18. (a) Hessian KO, Flynn BL. Org. Lett 2003;5:4377. [PubMed: 14602004] (b) Yue D, Larock RC. J. Org. Chem 2002;67:1905. [PubMed: 11895409] (c) Larock RC, Yue D. Tetrahedron Lett 2001;42:6011.

19. Flynn BL, Flynn GP, Hamel E, Jung MK. Bioorg. Med. Chem. Lett 2001;11:2341. [PubMed: 11527727]

20. Zhang X, Sarkar S, Larock RC. J. Org. Chem 2006;71:236. [PubMed: 16388642] 
21. (a) Yue D, Larock RC. Org. Lett 2004;6:1037. [PubMed: 15012094] (b) Yao T, Yue D, Larock RC. J. Comb. Chem 2005;7:809. [PubMed: 16283788] (c) Amjad M, Knight DW. Tetrahedron Lett 2004;45:539. (d) Barluenga J, Trincado M, Rubio E, Gonzalez JM. Angew. Chem., Int. Ed 2003;42:2406.

22. Zhang X, Campo MA, Yao T, Larock RC. Org. Lett 2005;7:763. [PubMed: 15727435]

23. Huang Q, Hunter JA, Larock RC. J. Org. Chem 2002;67:3437. [PubMed: 12003556]

24. Yao T, Larock RC. J. Org. Chem 2003;68:5936. [PubMed: 12868929]

25. Yue D, Della Cá N, Larock RC. Org. Lett 2004;6:1581. [PubMed: 15128241]

26. (a) Yao T, Campo MA, Larock RC. J. Org. Chem 2005;70:3511. [PubMed: 15844984] (b) Yao T, Campo MA, Larock RC. Org. Lett 2004;6:2677. [PubMed: 15281742]

27. Barluenga J, Trincado M, Marco-Arias M, Ballesteros A, Rubio E, Gonzalez JM. Chem. Commun 2005:2008.

28. Sonogashira, K. Metal-Catalyzed Cross-Coupling Reactions. Diederich, F.; Stang, PJ., editors. WileyVCH: Weinheim; Germany: 1998. p. 203-229.Chapter 5 (b) Sonogashira K, Tohda Y, Hagihara N. Tetrahedron Lett 1975:4467.

29. Berg TC, Bakken V, Gundersen L, Petersen D. Tetrahedron 2006;62:6121.

30. Muldakhmetov ZM, Agelmenev ME, Sovetov ES. Zh. Fiz. Khim 1999;73:2085.

31. Issei W, Junya I. Chem. Pharm. Bull 1963;11:1042. [PubMed: 5888548]

32. Pastine SJ, Youn SW, Sames D. Org. Lett 2003;5:1055. [PubMed: 12659572]

33. Tolstikov GA, Tolstikov AG, Miftakhov MS, Spirikhin LV. Zh. Org. Khim 1986;22:1620.

J Org Chem. Author manuscript; available in PMC 2008 September 2. 


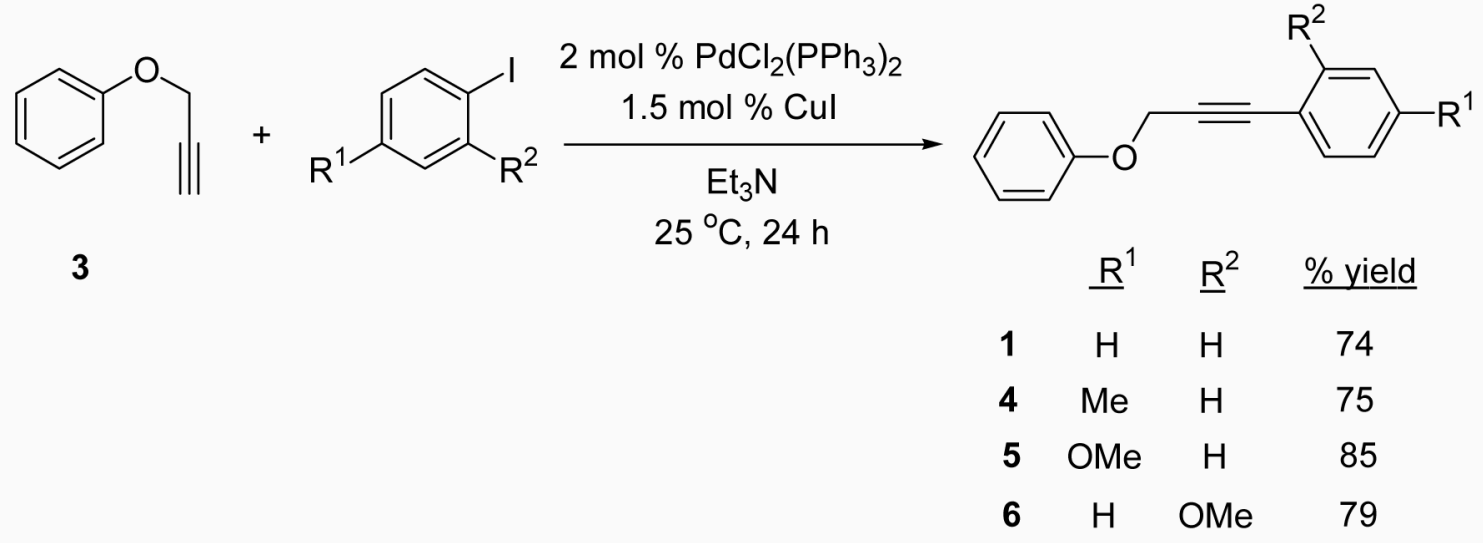

Scheme 1. 


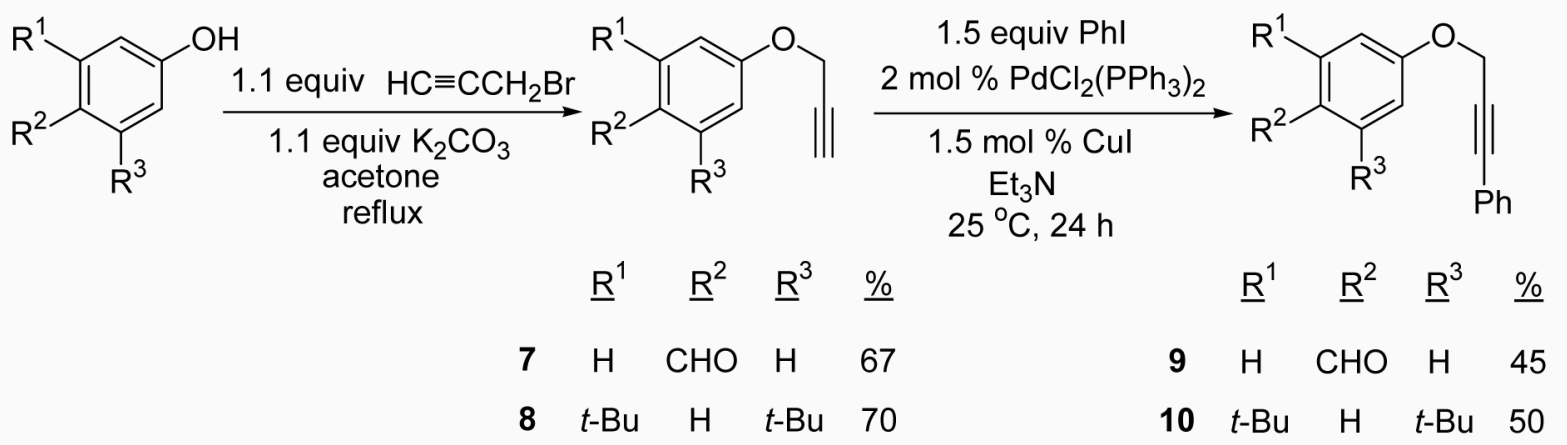

Scheme 2. 


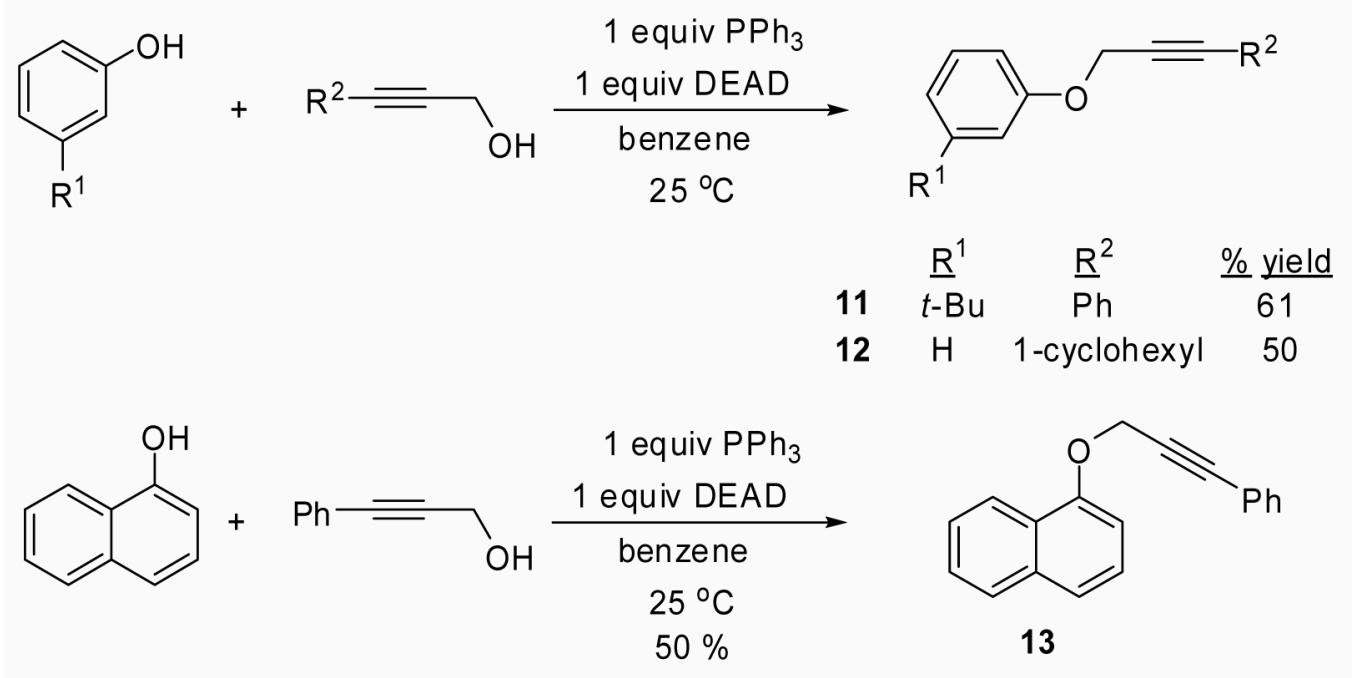

Scheme 3. 
<smiles>C(#Cc1ccccc1)COc1ccccc1</smiles>

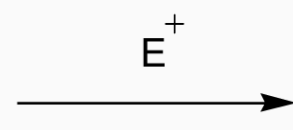

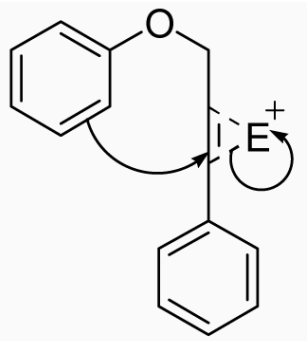<smiles>FC1=C(c2ccccc2)c2ccccc2OC1</smiles>
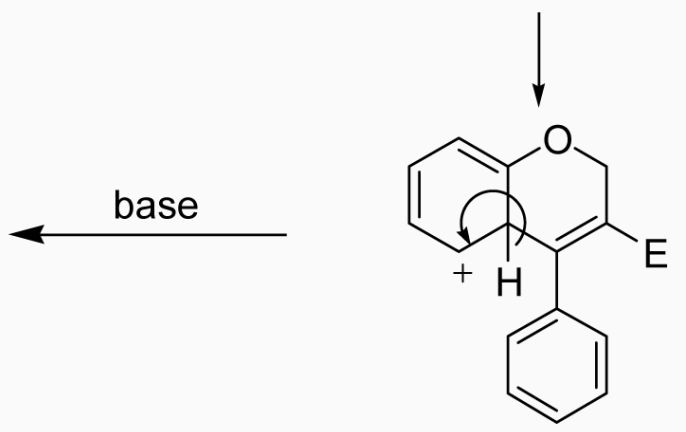

Scheme 4. 

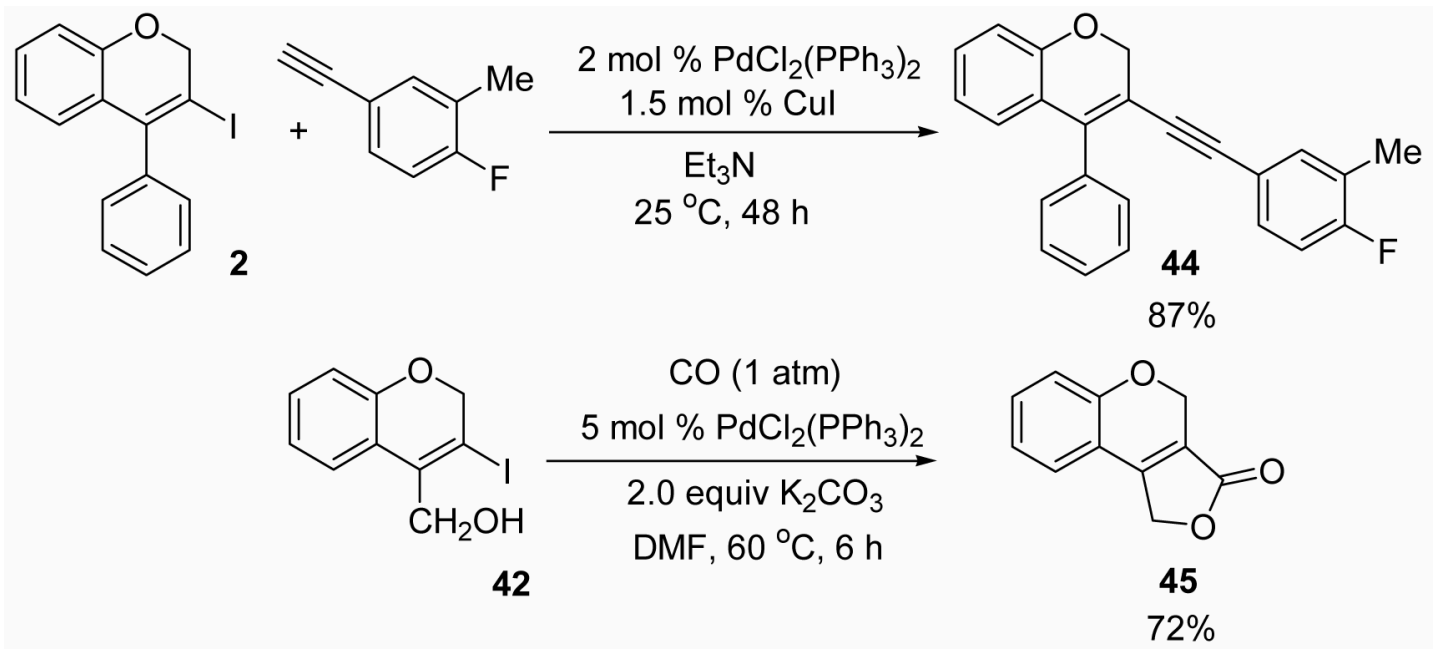

Scheme 5. 


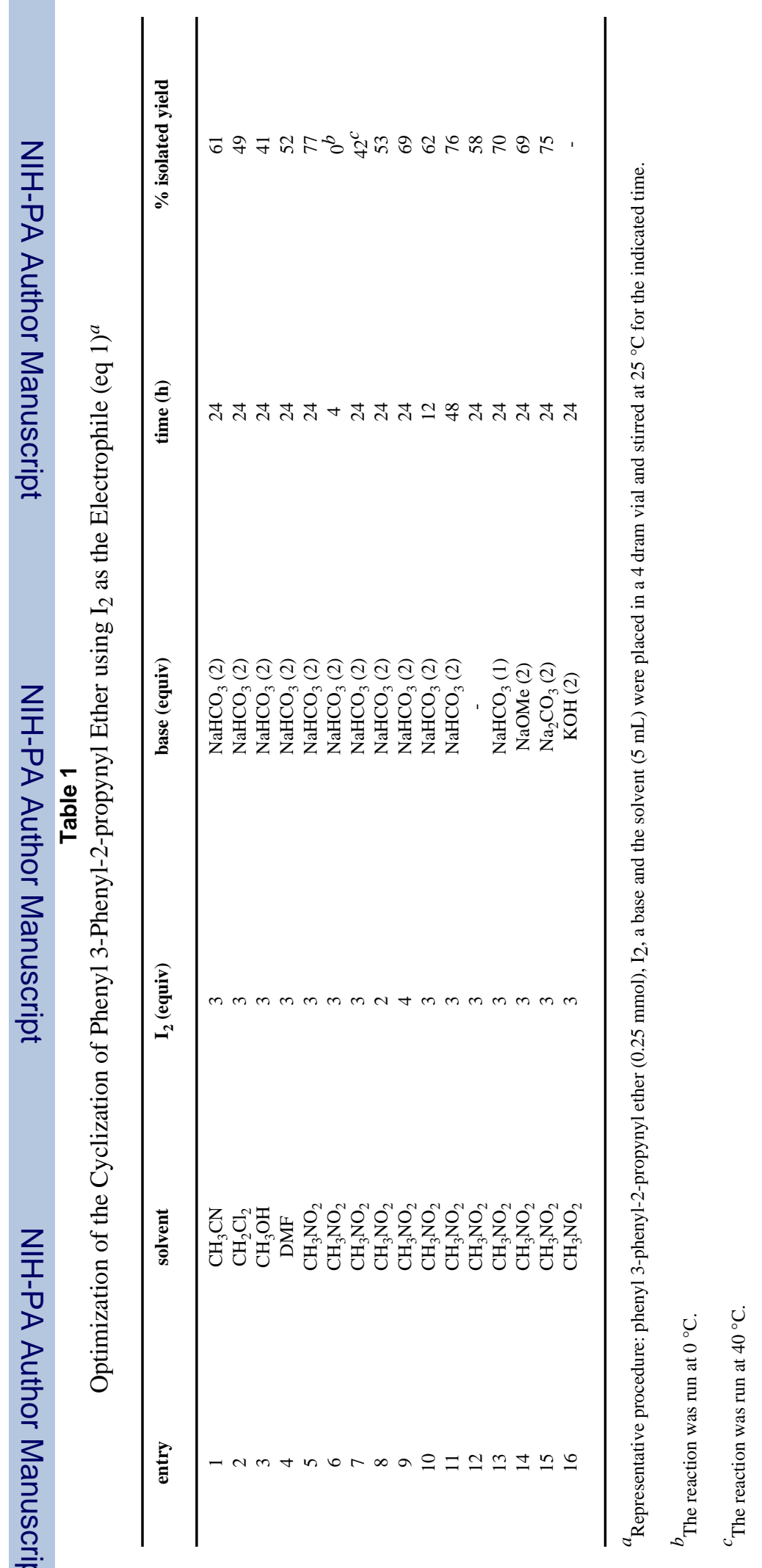




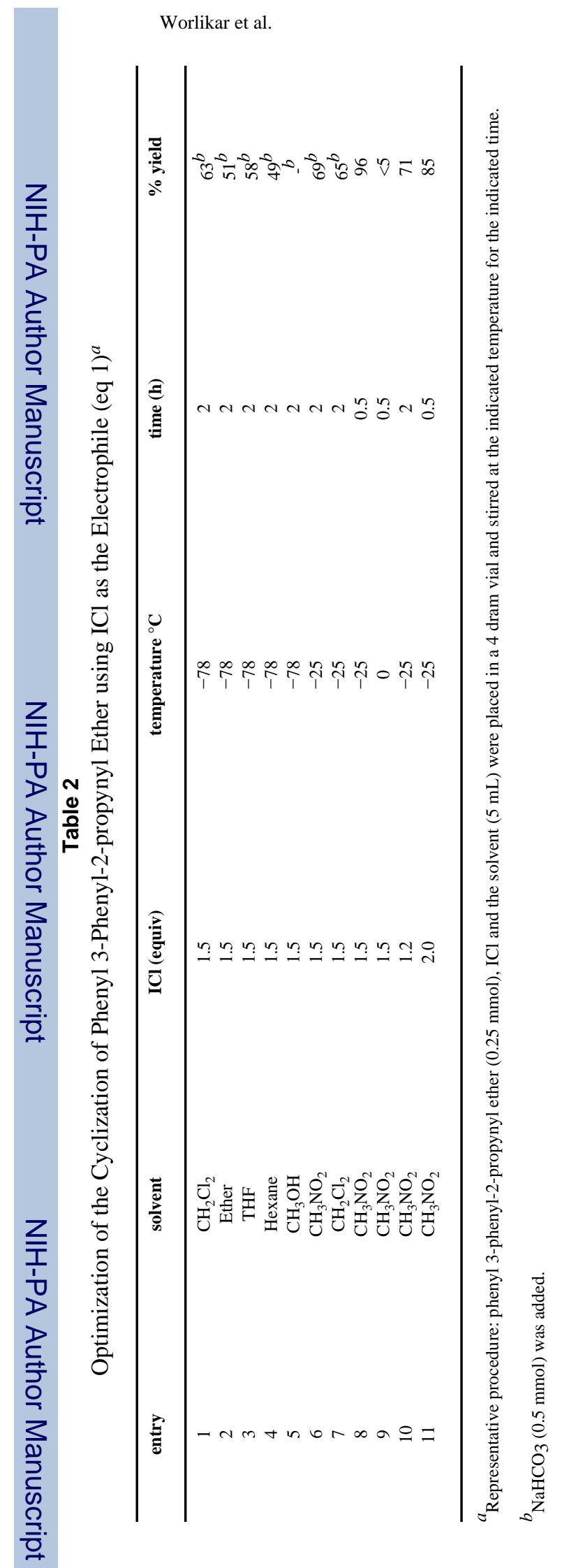

J Org Chem. Author manuscript; available in PMC 2008 September 2. 


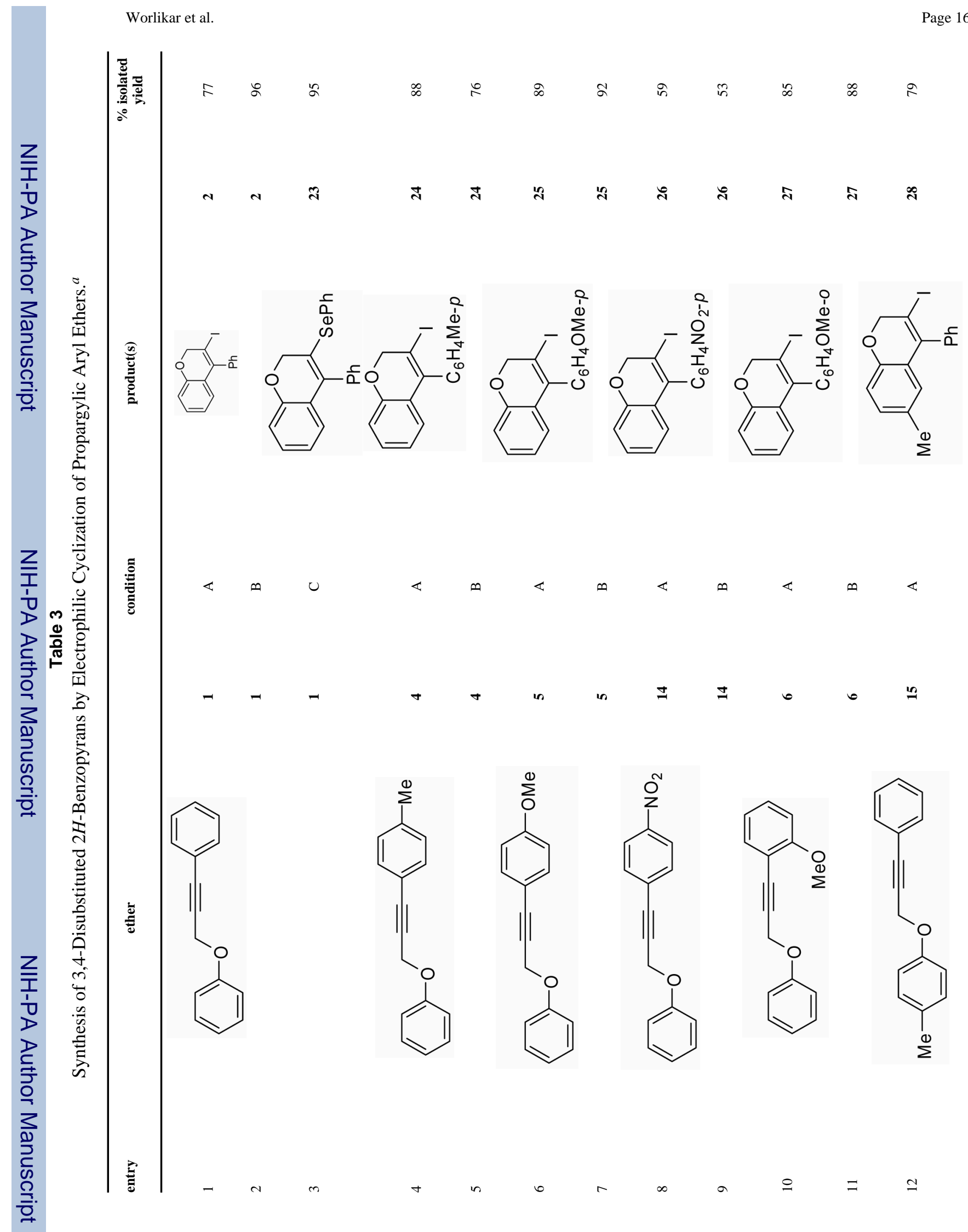

J Org Chem. Author manuscript; available in PMC 2008 September 2. 


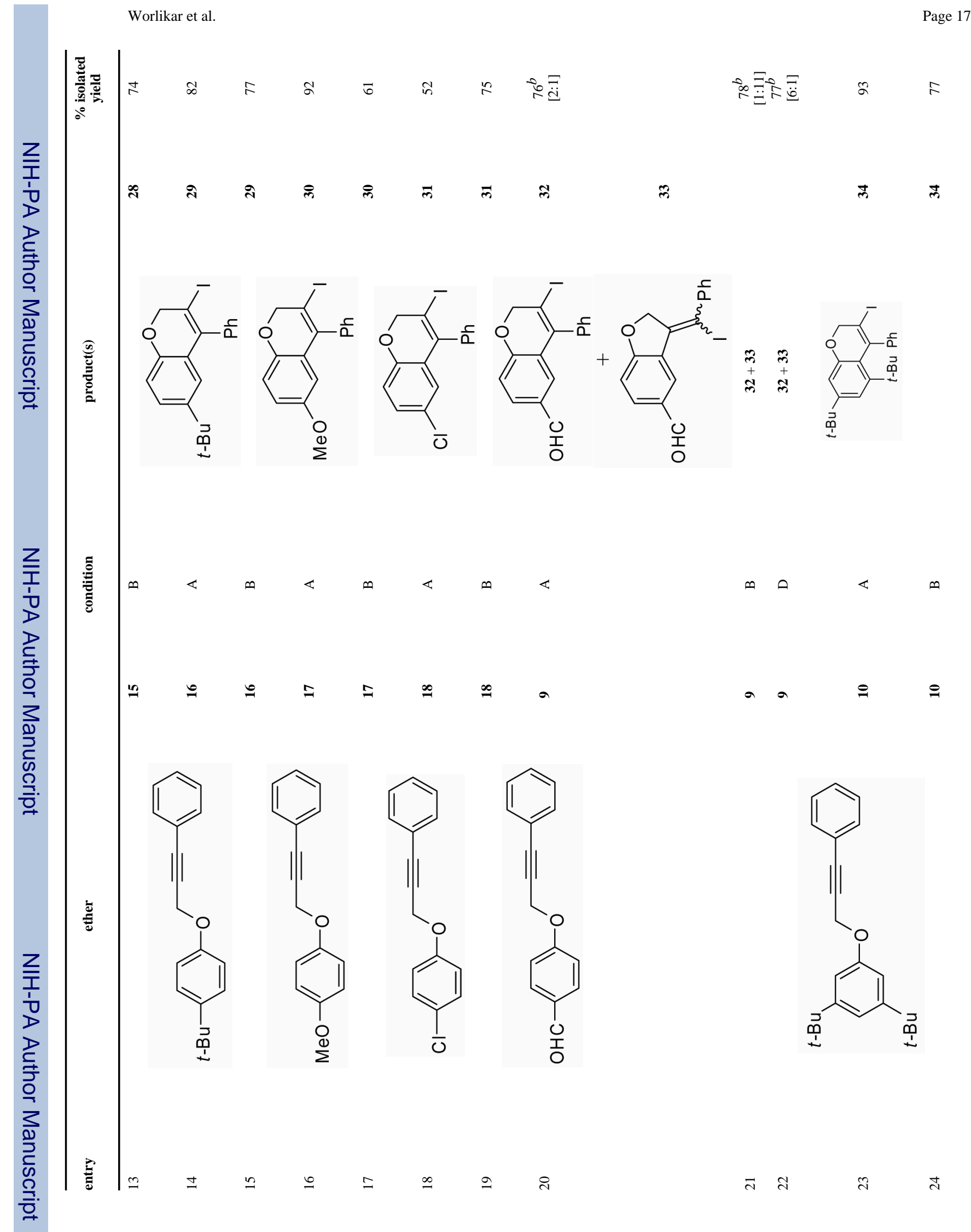

J Org Chem. Author manuscript; available in PMC 2008 September 2. 


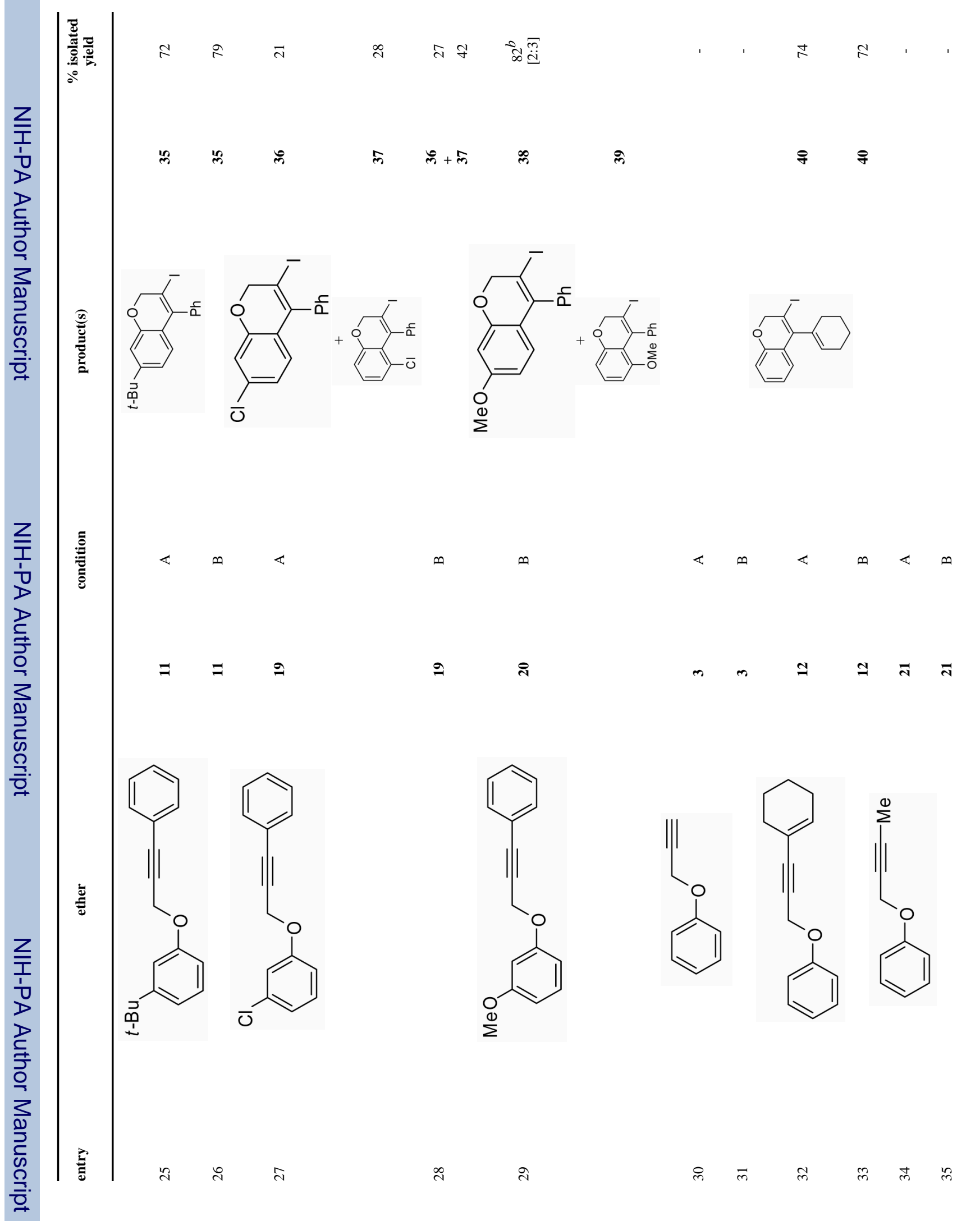

J Org Chem. Author manuscript; available in PMC 2008 September 2. 


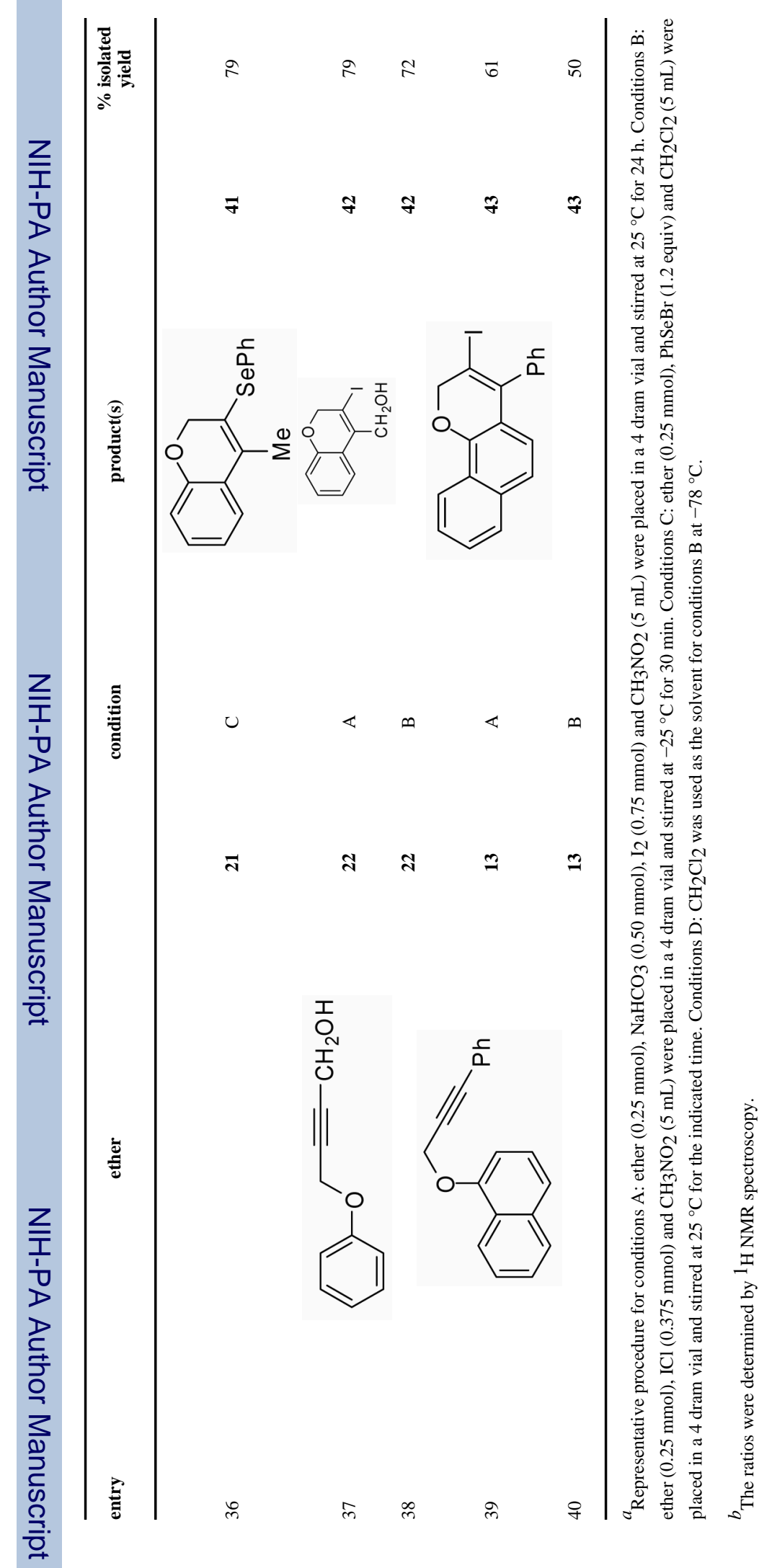

